\title{
MODIFICATION RECYCLE JUTE FIBRE WASTE FOR BULLET PROOF VESTS
}

\author{
By. Dewi Suliyanthini,Dr. Riza. W. Jonathan MM, \\ Dr Tinuk, and Aam. MSi. ${ }^{*}$
}

\begin{abstract}
This research uses experimental methods to find a formula modifications pure jute (Corchorus capsularis) and Javajute for textile composition strong and resistant to bullets, with the use of resin carbonanotubes (CNT) and tensile strength testing of physical evaluation and test-fired a fabric that can be accounted for laboratory. With methodology Kuantitatif Research and Develipment ( $R$ and $D$ ). Experiment by processing waste recycling Jute / Javajute into textile products. Jute / Javajute are plants that are often found on the coast of Indonesia, and has not done a lot of processing, it is generally discarded as useless waste. With experimental textile processing, waste jute / javajute be converted into bullet resistant textile products.
\end{abstract}

Long-term goal of this research is to get the right formula in terms of kompisisi fiber, basket type, and CNT resin composition, thereby answering a concern for domestic products and recycling waste back also unearth medium economic enterprises and SMEs in terms of plantation. The experimental results obtained that the tensile strength of jute fabric with or without CNT> $100 \mathrm{~kg}$, and the tensile strength of the fabric javajute without CNTs> $97 \mathrm{~kg}$, Javajute + CNT> 100kg.with Yarn Number Ne 11.

Test results using a pistol bullet caliber Revolfer II Internationa Standard Evaluationl (SII), weighs 9 gram bullet diameter of $9 \mathrm{~mm}$ bullets, bullet time speed of 341 $\mathrm{m} / \mathrm{s}$, Jute cloth + produced CNTs with 32 layers of clay sculpture penetration depth of 12 $\mathrm{mm}$. Jute cloth non CNT $12 \mathrm{~mm}$. Cain jute ResinCNT, 3,9kg $12 \mathrm{~mm}$. Cain jute non CNT $0,7 \mathrm{~mm}$. The experiment its goals if onlu 0,4 $\mathrm{mm}$ bullet .

For comparison in the Army agency, usually the fabric used for bulletproof Highcon types of PET imported products with a very high price. With a composition of 16-32 layers of PET weight between 21.9 to $30 \mathrm{gr}$. Where is the time of the shooting bullets lodged in the lining of the 11 for pistol caliber II and for rifle bullets lodged in the lining of 23-27. And than eksperiment for bullet vets ptoof FN25 pistol hurahara with sample same its success cannot mannequien body. Until linning 6 for jute CNT and linning 8 sample Jute. Weigth sample jute CNT $2.9 \mathrm{~kg} 32$ linning CNT resin 1\%, Weigth sample jute original 2,2 $\mathrm{kg} 32$ linning. This is a succes for pistol level 5.

Keywords: Jute, Carbonanotube (CNT) and bullet vest proof SII FN46 kaliber 09mm

\section{Latar Belakang}

Recycle atau daur-ulang limbah adalah topik pemikiran yang tiada hentinya untuk menjadikan produk baru dan terbarukan yang berdaya jual dan berdaya manfaat yang lebih baik dan baik lagi. Bertemakan daur-ulang limbah menjadi produk yang bermanfaat, dan memiliki pengetahuan tentang tekstil,

*Dosen Univeristas Negeri Jakarta 
limbah jute yang merupakan tanaman yang diperoleh dari pesisir pantai yang beriklim tropis dan banyak ditemukan di seluruh kepulauan Indonesia dirubah menjadi produk tekstil yang tahan peluru.

Seperti kita ketahui, sejarah Indonesia memenangkan Kemerdekaan di Masa lampau adalah karena hasil pemikiran perjuangan dan persatuan kesatuan para pahlawan Indonesia di Masa Ialu. Dengan dipersenjatai yang sangat tradisional, bambu runcing, dan hanya beberapa senapan, serta gundukan rami-jerami-jute sebagai pertahanan para pahlawan menahan tembusan peluru musuh penjajah, yang akhirnya kemenangan dari para penjajah itu dapat kita rasakan bersama sampai saat ini.

Berlandaskan sejarah dimasa lalu, ramijerami-jute adalah sejenis tanaman liar yang dapat menahan tembusan peluru para penjajah. Para Pejuang pada masa penjajahan sebelum kemerdekaan, menggunakan pakaian pelindung jenis jute ini. Pada sisi cerita lainnya, ternyata para pe-samurai China pun, dimasa lampau menggunakan.

Pelindung jenis Jute untuk melindungi dari tusukan samurai. Berdasarkan sejarah dimasa lampau ini, peneliti berfikir bahwa tanaman jute adalah tanaman yang memiliki suatu unsur yang dapat menahan tembusan peluru dan tusukan benda tajam. Dengan pengujian dan pengolahan tekstil modern dan canggih, maka limbah tanaman liar tersebut akan diolah menjadi produk tekstil yang tahan terhadap tembusan peluru.

Modifikasi komposisi jute akan memperoleh tekstil kuat, kokoh dan tahan peluru, disertai dengan proses resin anti peluru (resin
carbonnanotubes-CNT). Karena itu produk tekstil yang tahan terhadap peluru ini merupakan produk tekstil yang dapat digunakan untuk pakaian melindungi dari tembakan peluru atau dapat dikategorikan dalam strategi nasional.

Berdasarkan pemikiran tersebut diatas, maka penelitian eksperimen, dengan metode Research and Development $(\mathrm{RnD})$ yang mengevaluasi dan mendaurulang limbah jute menjadi produk pakaian tahan peluru sampai menemukan formula yang tepat setidaknya menyamai pakaian anti peluru produk import jenis Kevlar dan teruji secara valid di laboratorium berstandar Nasional/SNI dan atau SII dengan jenis senjata berkaliber.

\section{Kajian Teori}

\section{a. Jute}

Jute adalah serat yang didapat dari kulit batang tanaman Corchorus capsularis dan Corchorus olitorius. Serat jute telah dikenal sejak jaman Mesir kuno, dan diperkirakan berasal dari daerah sekitar laut tengah yang kemudian meluas di Asia. Kain jute pertamakali di ekspor ke Inggris oleh India pada akhir abad ke-18.

Tanaman jute yang ditanam untuk diambil seratnya mempunyai batang kecil, tinggi dan lurus. Tinggi pohon jute rata-rata 3 meter, dengan diameter batang 1-2 cm, daun-daunnya terutama terdapat pada bagian atas pohon.

Tanaman jute merupakan tanaman yang tumbuh baik ditanah alluvial, dengan iklim tropik yang lembab. Tanaman pada umumnya dapat dituai kurang lebih 120 hari setelah menyebaran biji.

Sampai saat ini belum ada standard grade untuk jute dapat diterima oleh semua pihak. Mutu serat dipengaruhi 
oleh daerah tumbuh, jenis, warna, kilau, kebersihan, panjang serat, dan pegangan, dan hanya dapat ditentukan oleh ahli-ahli yang sudah berpengalaman.

Kebanyakan eksportir mempergunakan klasifikasi yang disusun oleh London Jute Association sebagai berikut:

White jute : Firsts

\section{Lighthings}

Hearts

Tossa Jute : 2S/3S (ialah setengah nomor dua dan setengah nomor tiga)

$$
4 S
$$

$5 S$

Daisee jute : 2S/3S

$4 S$

$5 S$

Panjang serat elementer jute berkisar antara 1 - $5 \mathrm{~mm}$, dengan diameter 23u. Penampang lintangnya berbentuk segi banyak dengan sudut-sudut yang tajam, dengan dinding sel yang tebal dan lumen yang lebar berbentuk lonjong. Bentuk memanjang lumen tidak teratur, didekat dasar serat melebar dan didekat ujung menyempit, ujung seratnya meruncing.
Fibril-fibril serat jute membentuk spiral dengan arah putaran, sehingga serat akan berputar searah jarum jam bila dibasahi dan berputar berlawanan jarum jam pada waktu mengering dilihat dari ujungnya yang bebas. Sifat ini dapat dipergunakan untuk identifikasi serat jute.

\section{Komposisi serat jute.}

Komposisi utama serat jute mentah yang kuning adalah sebagai berikut:

Selulosa $71 \%$

Lignin $13 \%$

Hemi selulosa $13 \%$

Pektin $0,2 \%$

Zat-zat yang larut dalam air .... 2,3\%

Lemak dan lilin $0,5 \%$

Perbedaan utama antara jute dengan serat-serat batang yang lain ialah kadar lignin yang sangat tinggi. Belum diketahui ada tidaknya ikatan antara lignin dengan komponen-komponen yang lain. Ada dua jenis lignin didalam serat jute, yakni yang tidak larut dan yang larut didalam larutan asam encer.

Lignin adalah nama yang diberikan kepada sekelompok zat yang berada dalam dinding sel tumbuh-tumbuhan, terutama lapisan kayu yang strukturnya berdasarkan kerangka fenil propana

$\mathrm{H} \quad \mathrm{H}$

$-\mathrm{C}-\mathrm{C}-\mathrm{C}-\mathrm{H}$

$\mathrm{H} \quad \mathrm{H} \quad \mathrm{H}$

Misalnya coniferryl alkohol, dengan struktur sebagai berikut:

$\mathrm{HO}$<smiles>C1CCCCC1</smiles>

$\mathrm{OH}=\mathrm{CH}-\mathrm{CH}_{2} \mathrm{OH}$ 
Terdiri dari kerangka fenil propana tersebut, dan terdapat pada sel-sel yang belum dewasa kayu conifero. Kemungkinan coniferyl alkohol adalah permulaan dari molekul lignin.

Sifat khas molekul ini ialah dapat bergabung satu dengan yang lain dalam berbagai bentuk dengan adanya enzima yang terdapat dalam cairan kayu. Hal ini ditunjukan dengan banyaknya bentuk unit fenil propana dalam hasil penguraian lignin.

Lignin dalam tumbuh-tumbuhan dengan mudah dapat dihilangkan dengan cara khlorinasi karena terbentuknya kompleks khloro-lignin yang larut. Adanya lignin didalam zat-zat selulosa menaikan kepekaan selulosa terhadap perusakan oleh sinar matahari.

Hemiselulosa didalam jute berbeda dengan hemiselulosa yang terdapat pada serat batang lainnya. Hemiselulosa jute yang khas adalah xylose, yang struktur kimianya hampir sama dengan selulsa tetapi tidak mempunyai gugus $\mathrm{CH}_{2} \mathrm{OH}$.

Panjang rantai hemiselulosa jauh lebih pendek dari rantai selulosa, dan larut dalam alkali encer. Derajat polimerisasi rata-rata xylose adalah 120 .

\section{Sifat sifat serat.}

Adanya hemiselulosa menyebabkan jute lebih peka terhadap alkali dan asam daripada selulosa murni. Proses pemutihan yang kuat menyebabkan kehilangan berat yang cukup jelas, meskipun didalam praktek hanya sedikit sekali serat jute yang diputihkan. Jute yang belum diputihkan sangat peka terhadap sinar matahari dan dalam penyinaran yang lama warnanya berubah menjadi kuning atau coklat dan kekuatannya berkurang. Hal ini disebabkan oleh kadar lignin yang tinggi.

Serat jute mempunyai kekuatan dan kilau sedang, tetapi mulur saat putus rendah hanya $1,7 \%$ dan getas. Seratnya kasar sehingga membatasi kehalusan benang yang dapat dihasilkan. Sifat penting yang lain dari jute ialah sifat higroskopisnya lebih tinggi dibanding dengan serat-serat selulosa yang lain.

Pada kondisi standar, moisture regain serat jute $12,5 \%$. Jute tahan terhadap perusakan oleh mikroorganisme tetapi setelah pengerjaan asam atau basa, dan juga setelah penyinaran yang lama, sifat ini berkurang. Dalam pengolahan ujungujung serat elementer dapat terlepas dari bundelnya sehingga benangnya berbulu dan menyebabkan pegangannya kasar.

Tanaman jute yang banyak berada di Indonesia adalah jenis rosela (java jute). Rosela adalah serat yang diambil dari tanaman Hibiscus sabdariffa, terutama ditanam di Indonesia didaerah Jawa tengah dan Jawa Timur.

Di Indonesia java jute ditanam sebagai tanaman tahunan dan hanya menghasilkan satukali panenan setiap tahun karena adanya musim kemarau. Serat diambil melalui proses-proses pembusukan, pemisahan serat dan pencucian. Setelah pembusukan selesai 
serat dipisahkan dari kulit dengan cara pencucian. Cara ini memerlukan waktu pembusukan yang lebih pendek dan tenaga buruh yang lebih kecil dibandingkan dengan pembusukan seluruh batang. Produksi java jute pertahun berkisar antara 270 sampai $900 \mathrm{~kg}$ per-acre dan rata-rata berkisar antara 360 sampai $540 \mathrm{~kg}$.

Serat java jute yang baik berwarna krem sampai putih perak, berkilau dengan kekuatan yang cukup baik. Panjang serat antara 90 sampai $150 \mathrm{~cm}$. Panjang serat elemnternya antara 1,25 samapai $3,25 \mathrm{~mm}$ dengan rata-rata $1,75 \mathrm{~mm}$ dan diameter serat 10 sampai $32 u$, dengan rata-rata $29 u$. Bentuk mikroskopiknya sama dengan jute, dan sifat java jute sama seperti sifat jute.

\section{Rosela (Java Jute)}

Rosela adalah serat yang diambil dari tanaman Hibiscus Sabdariffa. Terutama ditanam di Indonesia ( Jawa tengah dan Jawa Timur). Selain di Indonesia, rosela juga ditaman di India, Bangladesh, Ceylo, Filiphina dan Hindia Barat, tetapi hasilnya kesil.

Bentuk tanaman rosela hampir sama dengan tanaman kenaf. Batang dan daunnya berwarna hijau tua sampai kemerahan dan bunganya putih krem sampai kuning. Rosela adalah tanaman yang berumur panjang dan pada suhu yang sesuai dapat menghasilkan dua panenan tiap tahun. Meskipun demikian dibeberapa daerah dapat ditanam sebagai tanaman tahunan karena pada umumnya akarnya tidak tahan terhadap penebangan batang berkali-kali, dan dibeberapa daerah musim pertumbuhan tidak kontinu.

Rosela tumbuh baik ditanah yang cukup subur dan gembur, dapat mengalirkan air dengan lancar, didaerah tropica atau sub-tropica yang bebas dari angin kencang dengan curah hujan yang cukup kira-kira $25 \mathrm{~cm}$ perbulan dalam masa pertumbuhan.

Biji-biji disebar dengan sangat rapat dan penyiangan dilakukan sampai daun-daun tanaman dapat melindungi tanah, kirakira 4-6 minggu seteah tanaman mulai tumbuh.

Penuaian dilakuakan apabila tanaman telah berbunga, biasanya 110 - 130 hari setelah penanaman, bergantung pada kondisi penanaman.

Di Indonesia rosela ditanam sebagai tanaman tahunan dan hanya menghasilkan satukali panenan setiap tahun karena adanya musim kemarau.

Dibeberapa daerah termasuk Indonesia serat diambil melalui prosesn pembusukan, pemisahan serat dan pencucian seperti halnya serat jute.

Di Ceylon, segera setelah pemotongan, kulit batang beserta serat yang menempel padanya dipisahkan dari batang. Kemudian kulit dan serat tersebut ibusukkan. Setelah pembusukan selesainserat dipisahkan dari kulit dengan cara pencucian.

Cara ini memerlukan waktu pembusukan tang lebih pendek dan tenaga buruh yang lebih kecil dibandingkan dengan pembusukan seluruh batang. Produksi serat per tahun berkisar antara 270 samapai $900 \mathrm{~kg}$ per arce dan rata-rata berkisar antara 360 sampai $540 \mathrm{~kg}$.

\section{Serat Rosela}

Serat rosela yang baik berwarna krem sampai putih perak, berkilau dengan kekuatan yang cukup baik.

Panjang serat teknik antara 90 sampai $150 \mathrm{~cm}$, sedang panjang serat-serat 
elementernya antara 1,25 sampai 3,25 $\mathrm{mm}$, dengan rata-rata $1,75 \mathrm{~mm}$ dan diameter serat 10 sampai $32 u$, dengan rata-rata 29ų. Brntuk mikroskopik serat hampir sama dengan serat jute.

Kekuatana kering serat rosela sedikit lebih rendah daripada serat jute tetapi dalam keadaan basah kekuatan serat rosela tetap, sedangkan kekuatan jute menurun; mulur saat putusny hampir sama. Serat rosela terutama dipergunakan untuk karung pembungkus gula dan beras.

\section{b. CarbonNanotube(CNT)}

Pada pertengahan 1980, Smalley dan koleganya di Rice University mengembangkan struktur kimia karbon yang disebut sebagai Fullerene. Fullerene adalah struktur karbon heksagonal dan pentagonal yang sambung menyambung. Carbon nanotube (CNT) adalah jenis fullerene yang berbentuk silinder dengan dinding karbon heksagonal (struktur grafit) dan seringkali tertutup pada kedua sisinya.

Jenis karbon ini telah menunjukkan sifat material yang unik. Banyak peneliti telah melaporkan kekuatan mekanik CNT yang melebihi kekuatan mekanik material yang sudah adal. Walaupun sifat pastinya masih dilaporkan bervariasi, hasil eksperimen dan pemodelan menunjukkan modulus elastis CNT yang lebih besar dari 1 TPA dan 10-100 kali lebih kuat dari baja bila dibandingkan dengan berat yang sama. Dengan laporan-laporan yang ada, CNT diklasifikasikan sebagai suatu kelas baru dalam material baru.
Selain dari segi sifat mekanik, CNT juga memiliki sifat termal dan elektrik yang baik. Material ini stabil secara termal hingga $2800{ }^{\circ} \mathrm{C}$ dalam vakum, memiliki konduktivitas termal sekitar dua kali konduktivitas termal intan, dan konduktivitas listriknya hingga 1000 kali konduktivitas listrik tembaga. Dengan sifat ini, CNT dikembangkan dalam berbagai peralatan mikroe-elektronik.

\section{Struktur atom dan morfologi CNT}

CNT digambarkan sebagai lembaran grafit yang digulung sehingga membentuk pipa. Berbeda dengan intan, yang membentuk kristal kubik tiga dimensi, grafit adalah karbon yang tersusun secara dua dimensi dari lapisan-lapisan heksagonal. Artinya, setiap karbon memiliki tiga tetangga terdekat. Dengan "menggulung" lembaran grafit tersebut, terbentuklah CNT. Sifat dari CNT tergantung dari susunan atom (bagaimana CNT ini "digulung"), diameter dan panjang pipa, dan morfologi, atau struktur nano. Berdasarkan jumlah lembaran grafit pada dinding pipanya, CNT dibagi atas CNT berdinding banyak (Multi-walled CNT / MWCNT) dan CNT berdinding tunggal (Single-walled CNT/SWCNT).

Karena struktur grafit yang berbentuk heksagonal, lapisan karbon ini dapat "digulung" dengan dua cara, yang disebut sebagai chirality. Akibatnya, struktur atom CNT bisa berbentuk armchair ataupun zig-zag, seperti pada gambar 1. Dilaporkan bahwa struktur armchair bersifat lebih ulet dibandingkan struktur zigzag. 


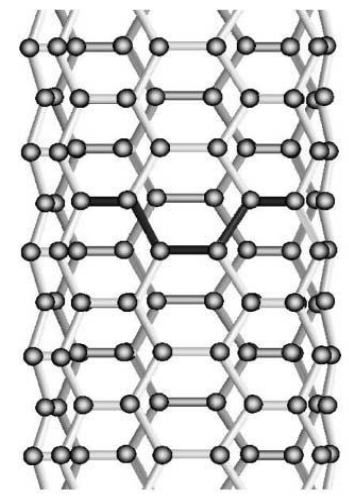

(a)

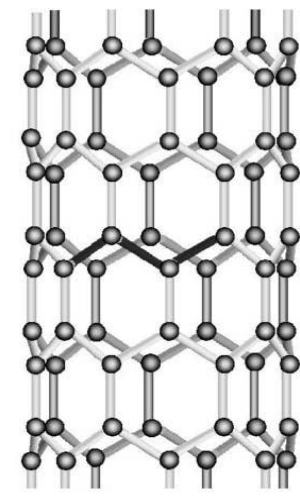

(b)

Gambar . Ilustrasi struktur atom (a) armchair dan (b)zigzag [2]

Dalam penggunaannya, struktur heksagonal (segi 6) dari carbon dapat berubah dengan adanya beban dari luar. Gambar 2 menunjukkan bahwa struktur heksagonal dapat berubah menjadi pentagonal (segi 5) dan heptagonal (segi 7). Pada saat mendapat beban tarik aksial. Fenomena ini disebut sebagai transformasi Stone-Wales.

Dengan adanya cacat tersebut, maka morfologi CNT dapat bervariasi. Kebanyakan CNT tidak berbentuk silinder lurus, namun terdapat lengkungan. Dengan demikian, perbedaan morfologi CNT tidak hanya berdasrkan pada perbedaan jumlah dinding (SWCNT dan MWCNT), namun juga pada bentuk keseluruhan ataupun lengkungannya.

\section{Potensi Penggunaan CNT}

Beberapa aplikasi CNT yang sedang dikembangkan di antaranya adalah dalam pembuatan otot buatan, baju anti peluru yang seringan kaos, perisai, dan selimut anti ledakan. Untuk aplikasi ini, dibutuhkan bahan yang lebih tipis, lebih ringan, dan lebih fleksibel dengan sifat mekanik dinamik yang tinggi seperti . Khusus untuk aplikasi tahan peluru dan ledakan, material terbaik adalah material yang dapat menyerap energi lebih tinggi dan dapat membuat peluru memantul atau berbelok. Saat ini, serat Kevlar banyak digunakan untuk keperluan baju tahan peluru karena memiliki ketangguhan yang tinggi ( $22 \mathrm{~J} / \mathrm{gm})$. Ketika peluru menembak baju tahan peluru, serat ini menyerap energi impak yang ditransmisikan dari peluru kebaju tahan peluru. Akibatnya, bukan baju yang rusak namun peluru yang terdeformasi. Kecepatan peluru berkisar antara 180 hingga $1800 \mathrm{~m} /$ det. Dilaporkan bahwa CNT dapat menahan peluru yang bergerak dengan kecepatan 200-1400 m/det.

Selain itu, dilaporkan juga bahwa kapasitas penyerapan energi dari CNT paling tinggi pada saat peluru mengenai bagian tengah dari CNT dan penyerapan energi dapat ditingkatkan dengan meningkatkan jari-jari pipa CNT. Yang tak kalah penting adalah CNT yang telah ditembaki dapat menahan peluru dengan kecepatan yang hampir sama 
dengan peluru pertama. Hal tersebut mengindikasikan bahwa CNT memiliki ketahanan balistik yang konstan pada titik yang sama.

\section{c. Proses Persiapan}

Kain tenun dihasilkan melalui proses menenun dengan anyaman tertentu dari benang-benang. Benang-benang tersebut terbagi dalam dua arah yang satu sama lain membuat sudut $90^{\circ}$. Atau dengan kata lain kain tenun dibentuk oleh benang yang arahnya vertikal yang disebut benang lusi dan benang yang arahnya horizontal yang disebut benang pakan.

Sebelum proses menenun dilaksanakan perlu adanya proses-proses persiapan yang meliputi proses:
1. Proses pengelosan (kalau diperlukan)
2. Proses perangkapan (kalau diperlukan)
3. Proses penggintiran (kalau diperlukan)
4. Proses penghanian
5. Proses penganjian
6. Proses pencucukan
7. Proses pemaletan

Proses-proses persiapan yang dilakukan pada benang lusi meliputi :
1. Proses pengelosan (kalau diperlukan)
2. Proses perangkapan (kalau diperlukan)
3. Proses penggintiran (kalau diperlukan)
4. Proses penghanian
5. Proses penganjian
6. Proses pencucukan

Sedangkan proses-proses persiapan yang dilakukan pada benang pakan meliputi :

1. Proses pengelosan (kalau diperlukan)
2. Proses perangkapan (kalau diperlukan)

3. Proses penggintiran (kalau diperlukan)

4. Proses pemaletan.

Tujuan utama dari proses persiapan meliputi :

1. Memperbaiki semaksimal mungkin kwalitas benang yang akan digunakan untuk membuat kain tenun, yaitu untuk mencegah kemungkinan terjadinya kesukarankesukaran / kemacetan-kemacetan pada proses menenun dan timbulnya kerusakan-kerusakan / cacat-cacat kain (defect).

2. Membuat gulungan-gulungan benang lusi dan benag pakan dalam bentuk dan volume tertentu yang disesuaikan dengan kebutuhankebutuhan pada proses menenun.

3. Mengatur bentuk dan kedudukan dari benang lusi dan mengatur bentuk benang pakan, sehingga pada proses menenun dapat dihasilkan kain tenun dengan design yang direncanakan.

Alat/ mesin tenun yang ditinjau dari caramenjalankannya dapat digolongkan menjadi:

1. Alat tenun gedogan tang dijalankan dengan tenaga tangan

2. Alat tenun bukan mesin (ATBM), yang dijalankan dengan kaki dan tangan

3. Alat tenun mesin (ATM), yang dijalankan secara masinal.

Baik ATMB atau ATM, keduanya memiliki prinsip kerja yang sama. Pembahasan mesin tenun yang ada hubungannya dengan tekstil design ialah peralatan atau mesin yang digunakan untuk 
menggerakan / mengangkat gun. Ditinjau dari segi peralatan penggerak gunini ada 4 macam jenis mesin tenun, ialah:

1. Mesin tenun dengan rol (kerek) dan eksentrik dalam

2. Mesin tenun dengan eksentrik luar

3. Mesin tenun dengan dobby

4. Mesin tenun dengan jacquard.

Anyaman Keper

Nama-nama lain dari anyaman keper yang banyak digunakan, yaitu twill (U.S.A), drill (Inggris), dan koper (Jerman).

Ciri-ciri/ karakteristik anyaman keper, yaitu :

- Anyaman keper adalah anyaman dasar yang kedua

- Pada permukaan kain terlihat garis miring atau rips miring yang tidak terputus-putus.

- (1) Jika arah garis miring berjalan dari kanan bawah ke kiri atas, disebut : keper kiri

(2) Jika arah garis miring berjalan dari kiri bawah ke kanan atas, disebut : keper kanan

- (1) Garis miring yang dibentuk oleh benang lusi, disebut : keper efek lusi atau keper lusi.

\section{Metodologi}

Metode penelitian yang digunakan adalah eksperimen kuantitatif pendekatan Research and development $(\mathrm{RnD})$, dengan mendapatkan data hasil pengujian lab uji tembak Balitbang TNI AD. Dengan jenis senjata KOPASUS Baret Merah jenis FN 46 kaliber $09 \mathrm{~mm}$, berat peluru 9gram. Kecepatan peluru 341
(2) Garis miring yang dibentuk oleh benang pakan, disebut : keper efek pakan atau keper pakan.

- Garis miring membentuk sudut $45^{\circ}$ terhadap garis horizontal.

- Appeareance kain pada permukaan atas dan bawah berlainan.

- Jika rapot terkecil dari anyaman keper $=3$ helai lusi dan 3 helai pakan, disebut keper 3 gun.

- Anyaman keper diberi nama menurut. Misalnya : keper 3 gun, keper 4 gun, keper 5 gun dan seterusnya.

- Biasanya dibuat dalam konstruksi padat.

- Dalam kondisi yang sama (=faktor-faktor lain sama), kekuatan kain dengan anyaman polos lebih besar daripada kekuatan kain dengan anyaman keper.

- Pada umumnya tetal benang dibuat lebih tinggi daripada dalam anyaman polos.

- Pengaruh arah twist benang sangat besar terhadap kenampakan garis miring.

- Besarnya sudut garis miring dipengaruhi oleh perbandingan tetal lusi dan tetal pakan.

- Garis miring dengan sudut $45^{\circ}$, disebut keper curam (steeptwill).

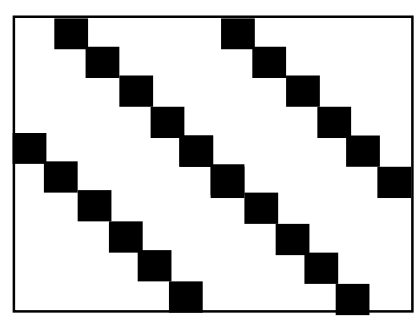

second/detik, jarak tembak 5 meter sesuai standard uji TNI berstandarkan Internasional, skala 1. Dan senjata anti 
huruhara jenis peluru karet penembak babi jarak tembak 10m, kecepatan peluru 276detik/second, berat peluru $5 \mathrm{gr}$.

Sampel uji adalah kain hasil pengolahan Jute dengan banyak sampel 5 contoh uji. Masing-masing sampel sebanyak 32 lembar kain sesuai dengan standar uji, dengan komposisi (1) 1 sampel kain original. (2) 1 sampel kain jute +CNT 1\% , (3) 1 sampel jute + CNT $2 \%$. (4) 1 sample Jute + CNT ultrasonic $5 \%$, (5) 1 sampel jute + CNT resin 5\%. Dengan kekuatan tarik benang $\mathrm{Ne}_{7}>100 \mathrm{~kg}$ untuk jute + CNT dan kekujatan tarik Jute original $\mathrm{Ne}_{7} 97 \mathrm{~kg}$

\section{Hasil Penelitian}

Berdasarkan hasil pengujian. Diperoleh data:

\begin{tabular}{|l|l|l|l|l|}
\hline No & Sampel uji & Berat kain & Uji tembak skala1 & Uji tembak skal5 \\
\hline 1 & Jute original & $2.2 \mathrm{~kg}$ & $07 \mathrm{~mm}$ & Pass -8 \\
\hline 2 & Jute+CNT1\% & $2.7 \mathrm{~kg}$ & $0.88 \mathrm{~mm}$ & Pass -8 \\
\hline 3 & Jute+CNT2\% & $3.7 \mathrm{~kg}$ & $0.9 \mathrm{~mm}$ & Pass -7 \\
\hline 4 & Jute+CNTresin1\% & $3.6 \mathrm{~kg}$ & $0.11 \mathrm{~mm}$ & Pass -8 \\
\hline 5 & Jute+CNTultra5\% & $2.9 \mathrm{~kg}$ & $0.7 \mathrm{~mm}$ & Pass -6 \\
\hline
\end{tabular}

Data hasil lab uji tembak balitbang Kopasus 2012 - 2013

Dari data tersebut diperoleh bahwa temuan formula pengolahan daur-ulang limbah jute + CNT mendekati titik sempurna atau rata-rata $0.8 \mathrm{~mm}$ untuk jenis senjata FN46 skala1 dan lapisan 7 untuk senjata anti huruhara skala5. Yang hamper menyamai Kevlar produk impor anti peluru 32 lapis berat $3,911 \mathrm{~kg}$, dengan lapisan nylon anti air dan keramik sehingga total berat jaket anti peluru $10 \mathrm{~kg}$. dengan asumsi tidak tembus peluru menganai sasaran bodylempung manequen. 


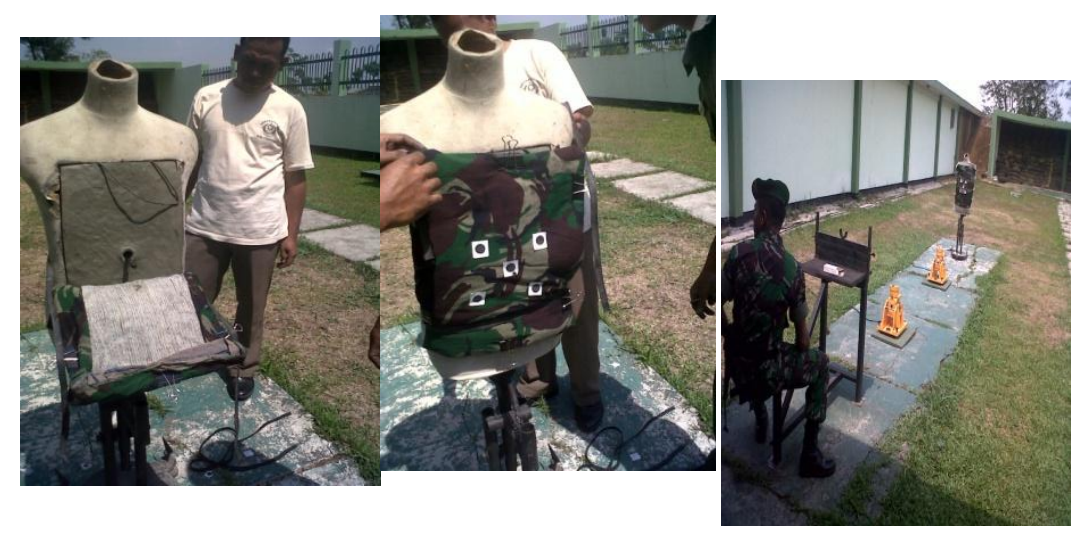

Foto jenis senjata FN46 kaliber 09mm skala 1 yang di gunakan uji penelitian :

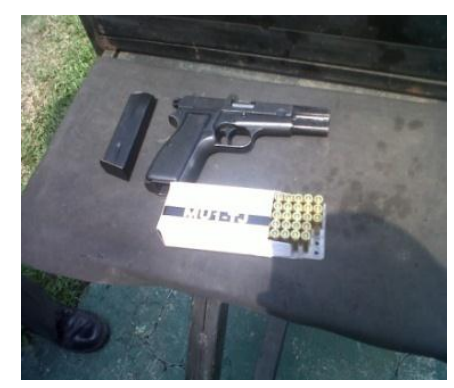

Foto lapisan Kevlar jaket anti peluru TNI-AD

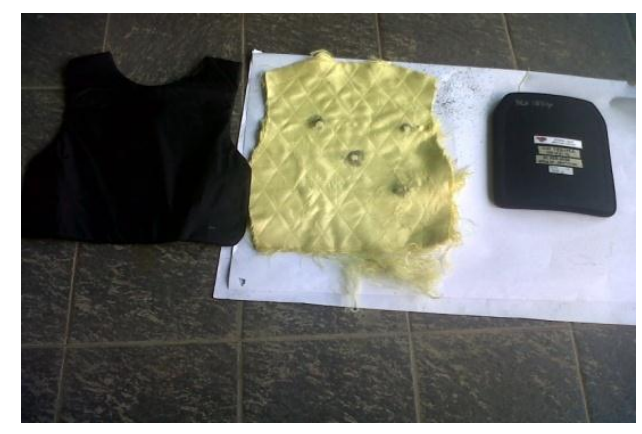

Berdasarkan hasil pengujian dan data yang diperoleh maka sampel penelitian kain jute dengan senjata skala 1 jenis
FN46 kaliber 09mm. memiliki data nilai belum sempurna atau temuan formula kain anti peluru masih harus di research 
and development lagi. Namun kain uji sampel Jute untuk pengujian senjata jenis huruhara dengan caliber jenis peluru karet penembak babi, temuan formula komposisi jute dan CNT dinyatakan sudah optimum benar, karena tembusan peluru bersarang pada lapisan kain rata-rata ke 8 pada sampel sebanyak masing-maisng 32 lapis. Hal ini menunjukan bahwa temuan formula jute + CNT yang peneliti eksperimen masih berada pada level 5 atau untuk senjata jenis anti huruhara jenis peluru karet pemburu babi. Berikut digambarkan dalam table garis perbedaan hasil uji tembak penelitian

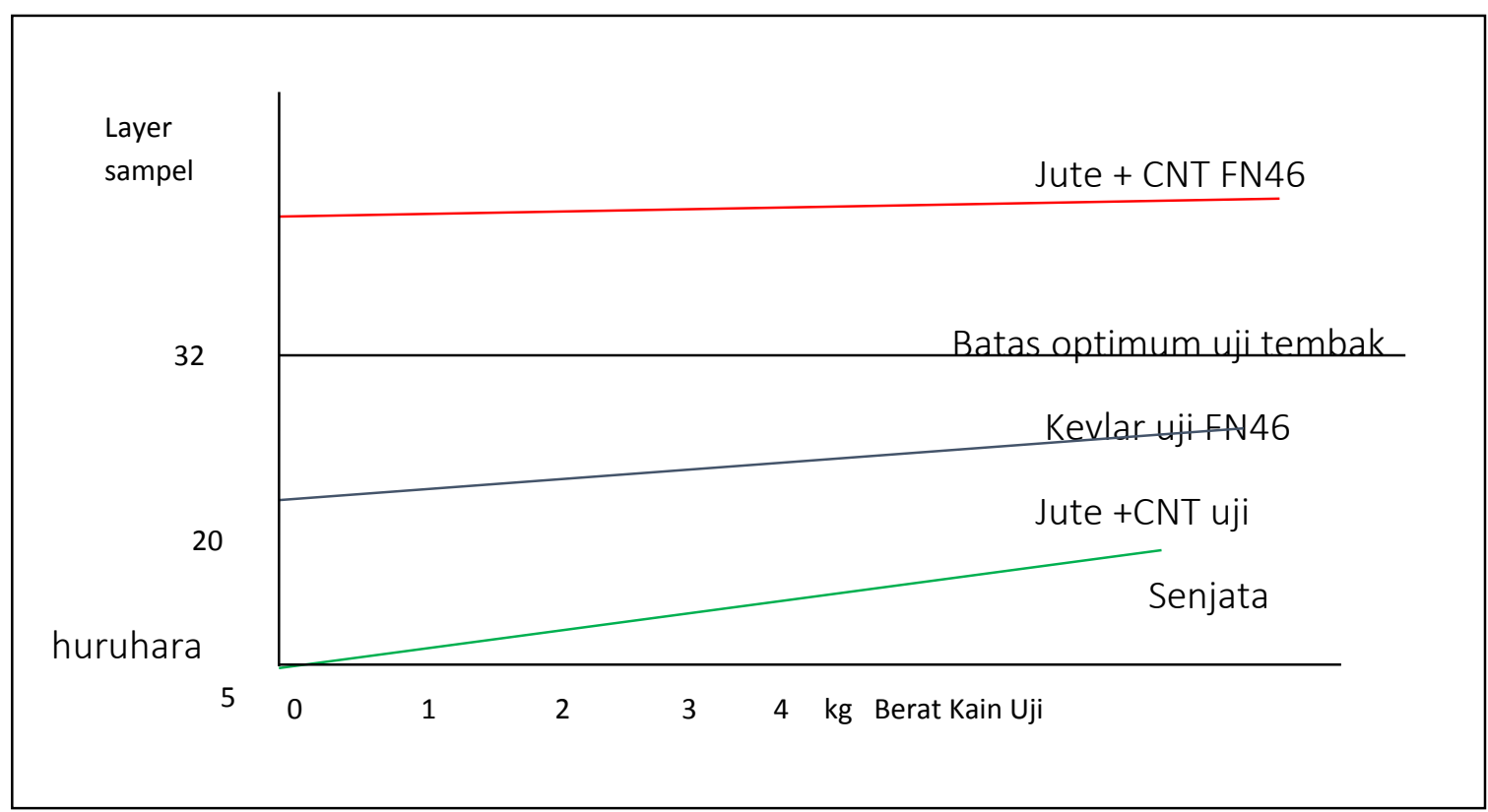

Gambar Grafik hasil uji tembak. 


\section{Kesimpulan}

Dari hasil penelitian ini ditemukan temuan formula untuk senjata huruhara jenis peluru karet pemburu babi, dengan komposiis jute + CNT 1\% anyaman keper 2/1 nomor benang Ne7 berat sample $3.1 \mathrm{~kg}$ sebanyak 32 layer menghasilkan tembusan peluru bersarang pada layer ke 7. Hal ini membuktikan bahwa temuan ini dikategorikan pada temuan senjata skala 5.

Namun untuk senjata jenis FN46, formula perlu dilakukan RnD kembali agar diperoleh komposisi yang tepat.

\section{Daftar Pustaka}

Agustien, Nyo dan Subandi, Endang. 1980. Pengetahuan Barang Tekstil, Jakarta. Departemen Pendidikan dan Kebudayaan.

A. J. Hall. 1970. Textile Finishing. London University.

Charles Effrin. 1970. Dyeing and Chemical Technology of Textile American Cotton and Cellulose. Hand Book. Vol. I. USA

Jumeri, dkk. 1977. Pengetahuan Barang Tekstil, Institut Teknologi Tekstil. Bandung.

Trotman, E.R. 1975. Chemical Technology of Textile Fibres, higwaycombe. Charles Griffin. Germany Ltd.

Walter Garmer. 1956. Textile Laboratory Manual. The National Trade Press. Lt.d. London. 